\title{
The Checkered Prehistory of Rice Movement Southwards as a Domesticated Cereal-from the Yangzi to the Equator
}

\author{
Peter Bellwood
}

Received: 11 October 2011 /Accepted: 30 October 2011 /Published online: 9 December 2011

(C) Springer Science+Business Media, LLC 2011

\begin{abstract}
This paper discusses the origins of Oryza sativa japonica rice cultivation in the Yangzi region of China and asks how and with which migrating human populations it spread south to reach Taiwan by 3,000 BC and Southeast Asia by 2,000 BC. The perspective adopted is that the spread of rice was driven mainly by demographic expansion, associated with a spread of languages and archaeological material culture. Environmental barriers also played major roles in establishing a "pause, adapt, spread, pause again" mode of movement, such barriers relating to availability of rainfall and alluvial land, latitude (photoperiodism) and climatic seasonality, and the prior presences of other populations, in some cases with vegetative gardening systems that did not involve rice or other cereals. Contingency also played its part in rice history, as we can see with the inability of this crop to spread into Oceania in part due to the route followed by Neolithic colonizers.
\end{abstract}

Keywords Oryza sative japonica $\cdot$ China $\cdot$ Southeast Asia . Oceania · Archaeology · Prehistoric migration · Linguistic history

\section{The cultivation and domestication of rice in China}

First, I put forward a number of suggestions regarding the initial cultivation and eventual domestication of Oryza sativa (subspecies japonica) and the consequent spread of the human populations who exploited and consumed it.

\section{P. Bellwood $(\square)$}

School of Archaeology and Anthropology,

Australian National University,

Canberra, ACT 0200, Australia

e-mail: peter.bellwood@anu.edu.au
Current genetic evidence suggests only one domestication of Oryza rufipogon, the ancestral perennial species for japonica, in or close to the Yangzi Basin ${ }^{1}$ (Molina et al. 2011; Zhao 2010; in this paper, I do not discuss the separate domestication of $O$. sativa subspecies indica from annual forebears in South Asia). This domestication occurred gradually between 7,000 and 4,000 $\mathrm{BC}$, commencing at the same time that summer monsoon rainfall and temperatures increased rapidly to levels that encouraged the growth of $O$. rufipogon northwards to Shandong (Zong et al. 2007). In addition, early Holocene global sea level rose $60 \mathrm{~m}$, between 9,650 and 5,000 BC, as a result of glacial melt water release (Smith et al. 2011), converting the wide coastal plain of eastern China into a much steeper coastline fringed with many offshore islands (see Fig. 1 for the former extent of this coastal plain). This rather phenomenal rate of climatic warming and coastal drowning was part of the transition from the Younger Dryas subglaciation of the terminal Pleistocene (c.10,800 to 9,500 BC) into the Holocene epoch of modern interglacial climate. Perhaps it is no coincidence that the oldest evidence for actual rice exploitation in the Yangzi Valley and its northern tributaries dates from this time span.

Prior to the Younger Dryas, wild rice had only a very tenuous presence in certain caves to the south of the Yangzi (Nakamura 2010). But fairly soon after the Younger Dryas, by at least 7,000 BC, the inland basin archaeological site of Shangshan in northern Zhejiang contained a small settlement of wooden pile dwellings with rice husk tempered

\footnotetext{
${ }^{1}$ In this paper the term "Yangzi Basin" is used loosely to refer to the whole drainage system of the middle and lower Yangzi river and its major tributaries both north and south, plus the lowlands that lie around Hangzhou Bay in Zhejiang Province. Before Christ (BC) chronology is used throughout for consistency.
} 


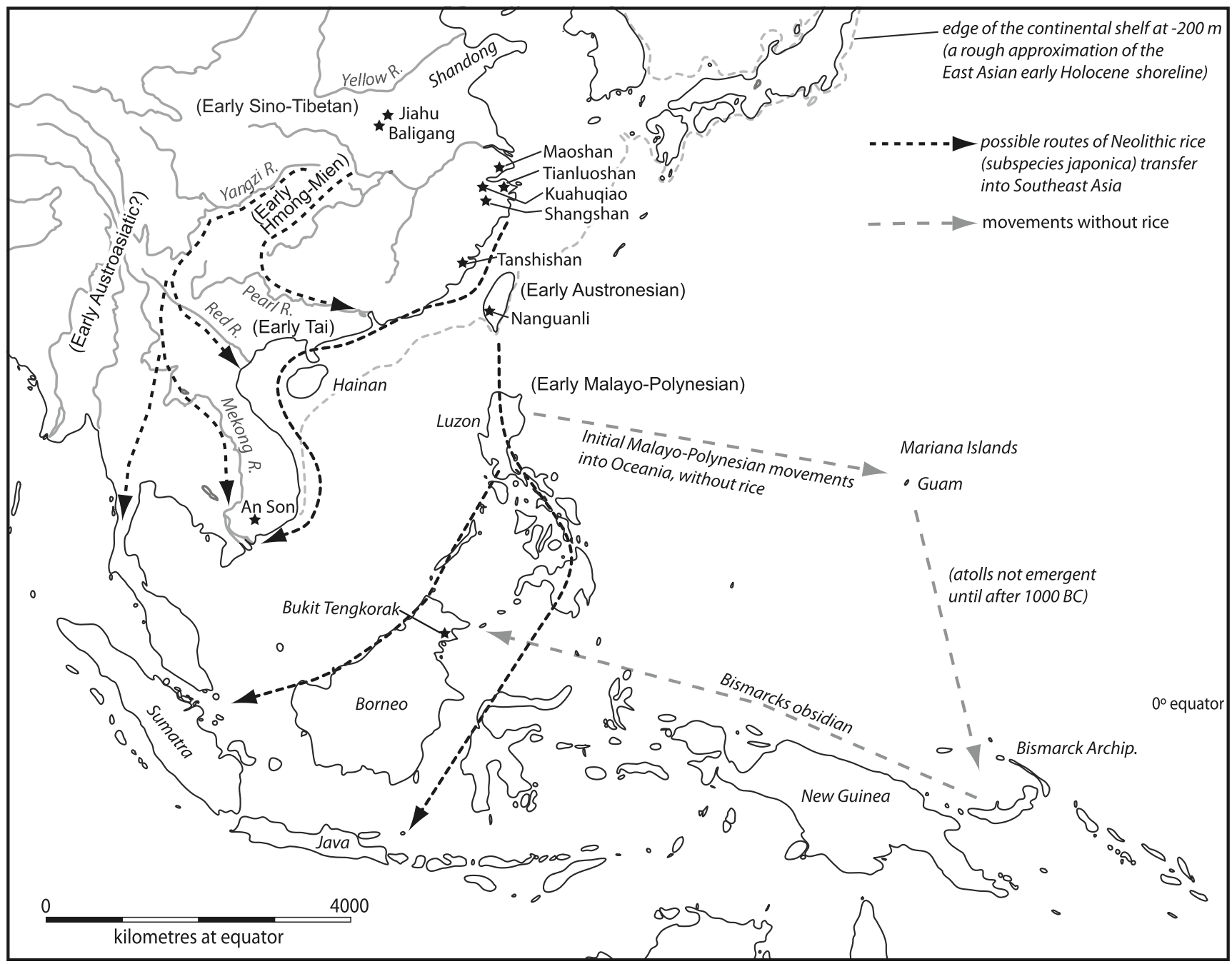

Fig. 1 China and Southeast Asia, to show archaeological sites, likely routes of early rice transfer, and possible language family homelands.

red-slipped pottery, polished stone axes, and grindstones (Jiang and Liu 2006). The rice was morphologically wild, but for the first time, we witness the possibility of human cultivation of rice and its deliberate threshing - the pottery contained chaff, not unprocessed whole grains (Zhao 2010). Similar evidence, also dating back to about 7,000 BC and including residue analysis in pottery as well as stable isotope dietary analysis of human bone, indicates rice consumption at the site of Jiahu in the Huai Valley, a northern tributary of the Yangzi in Henan Province (McGovern et al. 2004; Hu et al. 2006; Liu et al. 2007). On comparative Austroasiatic linguistic grounds, Ferlus (2010) suggests that rice was eaten first as a gruel of crushed and roughly husked grain. Only later was it boiled in loose grain form with a calculated amount of water to produce the "dry" dietary mainstay that so many people consume today. Diffloth (2011) also presents a strong case for a word meaning "husked rice" as a Proto-Austroasiatic reconstruction.
The idea that rice cultivation began close to the contemporary northern edge of the range of the wild plant, as a reaction to periodically adverse climatic circumstances, was to my knowledge first presented by Yan (1991: 125). It makes good sense, and a slight cooling of climate in central China at about $6,000 \mathrm{BC}$ was possibly a further stimulus to the development of domestication, by inducing humans to actually plant the rice to ensure a continuing and reliable supply. For instance, at the site of Baligang, on the Han tributary of the middle Yangzi in Henan Province, there is evidence for a rice and acorn economy in the pre-Yangshao archaeological phase at c.6,000 $\mathrm{BC}$, followed by a shift to millet in the Yangshao itself (c.5,000 BC), and then a return to rice in the subsequent Longshan phase (Deng Zhenhua, Peking University, personal communication 2011). Such fluctuations in the presence of rice might have reflected issues of availability and supply on the northern edge of its range. 
After Jiahu and Shangshan, further archaeological evidence for the intensification of rice exploitation comes from Kuahuqiao in northern Zhejiang (ZPICRA 2004; Zong et al. 2007). Dating to c.6,000 BC, this site has yielded a waterlogged canoe, wooden paddles, foundations of pile dwellings, a small proportion of morphologically domesticated rice (most grains still have wild morphologies) that resembles the japonica subspecies, and a possibility of pig domestication (Liu et al. 2007). By $4,600 \mathrm{BC}$, rice had risen at Tianluoshan to perhaps $30 \%$ of a plant food diet that also included acorns, water chestnuts, and foxnuts (Fuller et al. 2009). By 4,000 BC, nonshattering spikelet bases of carbonized rice grains had increased sufficiently in percentage in lower Yangzi sites (to between 40\% and 65\%) for Fuller et al. (2009) to accept that rice had become fully domesticated, a process that had progressed continuously for more than 2,500 years from the incipient stage of (mainly wild) rice cultivation represented at Jiahu and Shangshan.

Movement of rice in the early days of its cultivation to new locations where water availability was seasonal, rather than perennial, appears to have been crucial for its eventual domestication as an annual cereal. Hill (2009) and Fuller et al. (2009) suggest that the wild ancestor of domesticated rice, the perennial grass $O$. rufipogon, was originally harvested continuously in perennial swamps by ratooning. This practice produces lower yields than fresh planting of seed, but requires far less labor. However, humans eventually would have planted rice seeds outside permanent wetlands, perhaps in seasonally wet terrain where the climatic regime would have imposed selection for the annual growth habit that characterizes $O$. sativa. Outplanting away from wild stands would also have allowed any selection towards nonshattering to be retained more easily with each successive monsoonal planting season (Allaby et al. 2008). The implication here is that the very process of radiation and migration on the part of humans was an essential part of the domestication process for rice right from the start.

Under what kind of cultivation system did rice cultivation initially spread? Fuller and Qin (2009) have suggested that it spread originally as a wet field crop and also suggest that it spread as a result of increasing social complexity and intensification. However, the labor and land tenurial demands of intensive wet rice production, and the nature of the early Holocene environments of coastal China and Southeast Asia render this mode of production rather unlikely in a pioneer colonization situation, however much it might have spread among established and demographically increasing rice-growing populations in later periods.

In an economic context, fully irrigated wet rice, as recorded (for instance) in colonial Java, had an enormous ability to absorb an increasing labor input and to feed an increasing population. Geertz (1963) referred to this process as "agricultural involution," noting that wet rice intensification did not damage the environment because of the stability provided by terracing and field construction, and the constant renewal of nutrients by riverine flooding. Fully irrigated wet rice at this level can only spread slowly because of its need for high labor investment and stable tenurial arrangements in the establishment of new fields.

Kirch (1994) has noted a similar situation from a different perspective for wet taro (Colocasia esculenta) cultivation in the islands of Futuna and Hawai'i in Polynesia. Wet taro was a highly productive agricultural system in Polynesian prehistory that absorbed high quantities of labor and supported populous and powerful chiefdoms. However, predatory chieftainship and territorial expansion emanated not from such areas of plenty but from the dry and often overexploited landscapes on the leeward sides of many Polynesian islands. Shifting cultivation under conditions of periodic stress was the real recipe for expansion and land taking, not cropping from highly valuable and labor-intensive wet fields. Vayda (1961) made similar observations for groups such as the Iban of Borneo and the Tiv of Nigeria-shifting cultivation was often bound up with predatory and often very long distance expansion. The ethnographic rice swiddening Iban colonized river banks through perhaps $1,000 \mathrm{~km}$ of Borneo, from western Sarawak to Brunei, in under a century (see also Freeman 1970).

In the heartland of early rice cultivation in the middle and lower Yangzi Basin, it is likely that rice farming had already reached highly intensive levels by as early as 4,000 BC. Incipient wet rice field complexes date back to almost 5,000 BC at Tianluoshan (Zheng et al. 2009). Fuller et al. (2011) suggest that by $3,000 \mathrm{BC}$, the system was highly productive, capable of supporting the huge population of the Liangzhu phase in the lower Yangzi valley. ${ }^{2}$ The elongated Liangzhu wet rice fields at Maoshan, for instance, dating from c.3,200-2,400 BC, were separated by long paralleled bunds of fired soil about $20 \mathrm{~m}$ apart and covered an area of at least 50 by $700 \mathrm{~m}$, according to phytolith analysis (Qin Ling, Peking University, personal communication 2011). It seems unlikely that rice cultivation spread into Southeast Asia with the first farmers as a simple transplant of this Liangzhu intensive production system.

\footnotetext{
${ }^{2}$ The exact size and density of the Liangzhu population will never be known with certainty, but Zhang and Hung (2008) record for the nearby Dongting Lake region of Hunan Province (middle Yangzi) an increase from 22 small sites in the Pengtoushan Phase (6,000 BC) to 200 sites, including some very large ones, in the Qujialing-Shijiahe Phase (3,500-2,000 BC), contemporary with Liangzhu. For the lower Yangzi, Li et al. (2009, Table 2) record an increase from only three sites prior to $5,000 \mathrm{BC}$ to 517 by $2,000 \mathrm{BC}$.
} 
Indeed, there is every reason to expect that early agricultural expansion into and through a landscape of hunter-gatherers would have tended to emphasize those systems of production that minimized labor input, especially in situations where manpower was limited. We can see a parallel here in the first human settlement of the islands of Polynesia, including New Zealand, in which agriculturalist settlers (without rice) spent the first few decades of their occupation in a fairly avid reduction, even extirpation, of easily accessible and naïve bird and sea mammal resources. Investment of labor in wet taro fields appears to have been a late prehistoric activity in most island groups, fueled by population increase and the need for intensification of production (Kirch 2010; Spriggs 2011).

Another factor that would have inhibited the export of full-scale intensive wet rice agriculture was the nature of the early Holocene coastal terrain of East Asia, following the very dramatic postglacial rise of sea level. This transformed the eastern coastline of China from a coastal plain up to $700 \mathrm{~km}$ wide into an archipelago (Nakamura 2010, see Fig. 1). Modern sea level was reached generally by about $5,000 \mathrm{BC}$, but in areas of shallow continental shelf, such as Sundaland (western Indonesia) and the eastern coastline of China, isostatic loading by the weight of sea water would have caused crustal sinking to continue until well after this dated. Proske et al. (2010) dates the highest sea level $(+2.5 \mathrm{~m})$ to between 4,000 and 3,000 BC in what is today the Mekong Delta, and Sathiamurthy and Voris (2006) recognize a +5 -m-high stand for this area as recently as $2,200 \mathrm{BC}$. This means that rice cultivation was spreading southwards from central China at a time when the coastlines were maximally flooded by the Holocene sea level rise, and any perennial freshwater swamps beyond the range of tidal influence would have been of very limited extent. In the more fortunate situation of the Yangzi Delta, many of the early sites with rice appear to have been sheltered behind a series of chenier ridges that formed inland from Shanghai (Zong et al. 2007, Fig. 1; Zheng et al. 2009). But such favorable circumstances are unlikely to have been available along the more exposed coastlines of China, south of Hangzhou Bay.

Thus, Rolett et al. (2011) note that the Neolithic site of Tanshishan, in Fujian Province, now $75 \mathrm{~km}$ inland near Fuzhou city was located between 3,000 and 2,300 BC on an island in the inner and then estuarine Fuzhou Basin. No good deltaic land was available for wet rice agriculture, and the excavators think that the Tanshishan economy was still basically without reliance on rice. I have noted a similar situation for the coastline and rivers of Ilocos Norte in the northern Philippines (Bellwood et al. 2008); the Holocene sea level rise here drowned narrow incised valleys that were cut down to the last glacial maximum coastline over steep coastal terrain (the Philippines do not lie on a continental shelf), forming "fiords" flanked by steep slopes until human occupation and forest clearance allowed lowlands to accumulate alluvium and colluvium (cf. Spriggs 2011; Carson 2011, for identical situations in Oceanic islands at first colonization). Such coastal plain and valley sedimentation probably did not develop to any degree in Luzon until long after Neolithic farmers had impacted on the environment through burning and forest clearance, certainly long after 1,000 BC.

In mainland Southeast Asia, the only areas of alluvium that could have offered suitable areas for wet rice cultivation at 2,000 $\mathrm{BC}$, without a considerable input of labor on the part of the farmers, were presumably on the fringes of the largest riverine basins like the Pearl, Red, and Mekong (Proske et al. 2010). Island Southeast has only small riverine basins, and many regions outside Java and Bali had very poor potential for wet rice production owing to unfavorable equatorial climates, soils, and terrain (Pelzer 1948; Geertz 1963; Spencer 1966). If wet rice production was involved in farming expansions out of central China, it was surely at a very basic level without major investment in wet field infrastructure.

\section{Early rice and the linguistic record}

The major language families of Southeast Asia (Austronesian, Austroasiatic, Tai, Hmong-Mien, and Sino-Tibetan) all have reconstructable proto-vocabularies that suggest an early and deep acquaintance with rice and its exploitation (Zorc 1994; Sagart 2003; Ferlus 2010; Ratliff 2010; Wolff 2010; Diffloth 2011). In the Austronesian case, this could imply, on linguistic grounds, a familiarity with both wet and dry rice as well as with transplantation techniques (Sagart 2003). Sagart also favors a dual origin for rice vocabularies, one within Austroasiatic and another within Tai and Austronesian. Allowing that rice cultivation was first developed in a generalized Yangzi source region, this could suggest a dual expansion of rice vocabulary, on the one hand involving coastal China from southern Shandong southwards to Hainan and Taiwan [Austronesian and Tai, with (Sagart 2005a, 2008) suggested links to Sino-Tibetan] and on the other hand an inland riverine Austroasiatic dispersal (Sidwell 2010).

The heavily overlain distribution of the Austroasiatic language family means that it no longer has a precisely reconstructable homeland, but Diffloth (2005) suggests close to the Bay of Bengal, while Sidwell (2010) favors a Mekong Basin origin. Has evidence for a now invisible Yangzi homeland for Austroasiatic been erased by Sinitic language expansion? Or was Austroasiatic dispersal a result of a domino effect, with populations of ultimate Yangzi origin introducing rice cultivation to a Southeast Asian (early 
Austroasiatic) linguistic population located outside the Yangzi Basin, which then expanded further in its own right?

The archaeological record can never prove or disprove linguistic homeland and migration hypotheses such as these, but it can render some more likely than others. For instance, Zhang and Hung (2010) use purely archaeological evidence to suggest expansions of rice cultivation from the Yangzi basin via two routes like those just derived from the linguistic evidence: one coastal from Zhejiang down to Fujian and Taiwan, and the other by inland valleys from the middle Yangzi to Guangxi and the SE Asian mainland. The two streams perhaps met, and mixed, in Guangdong. Such observations could make a central or southern Chinese origin for rice vocabularies rather likely.

Sagart's (2005b) suggestion of a Taiwan or northern Philippine origin for the Tai language family, as a cousinly subgroup to Malayo-Polynesian, is difficult to assess archaeologically because of the relative lack of Neolithic information from the key Chinese provinces of Hainan, Guangdong, and Guangxi. Evidence for rice cultivation only reached these regions, like Taiwan, around 3,000 BC, possibly not until 2,000 BC in the case of northern Vietnam (Zhang and Hung 2010). Early Neolithic links in artifact assemblages between Taiwan and the Pearl Delta region of Guangdong have been suggested (e.g., by Tsang 2005: 71), but the archaeological record at this stage is too thin to allow any real testing of Sagart's hypothesis for Tai.

However, there is good evidence for considerable population growth in Taiwan from the Early Neolithic (3,500 BC) onwards to the Middle Neolithic at about 2,000 BC. Liu (2007: 55) records, for the Danshui River near Taipei, an increase in settlement numbers from 3 in the early Dabenkeng (earliest Neolithic) phase to more than 20 in the middle Dabenkeng, then to more than 50 in the following Middle Neolithic Shuntanpu phase at c.2,000 BC. He notes also that Middle Neolithic sites elsewhere in Taiwan can be up to 20 to 30 times larger than Dabenkeng sites (e.g., 60 ha for Niuchouzi). For eastern Taiwan, Hung (2005) documents only five Dabenkeng sites dating from c.3,500 to 2,500 BC, then 43 Middle Neolithic sites dating between 2,500 and 1,500 BC. So the period from 3,500 to $2,000 \mathrm{BC}$ was clearly one of considerable population growth throughout the island.

Likewise, for the sandy and windswept Penghu Islands in Taiwan Strait, Tsang (1992: 60-62) records a total of only four Dabenkeng sites but 32 Middle Neolithic sites (c.2,500-2,000 BC). However, there was then a sharp decline to only four sites dated to the interval $2,000-1,500$ $\mathrm{BC}$, after which these islands appear to lack subsequent occupation until the Chinese historical period, within the past 1,000 years. There is a possibility here that colonization by a Neolithic rice growing population led to such high levels of population growth and environmental over- exploitation (deforestation?) that these islands were actually abandoned for agriculture for about 2000 years after $1500 \mathrm{BC}$. It is thus most interesting that the movement of Neolithic populations from Taiwan into the northern Philippines can now be dated with considerable confidence to about 2,000 BC (Bellwood and Dizon 2005, 2008; Hung 2005), thus at or just after a time when both the Taiwan and Penghu sequences reveal very high population densities. A contemporary movement of Taispeaking populations along the lines suggested by Sagart is therefore not impossible on demographic grounds, even if archaeological evidence for or against it is currently lacking.

\section{Early rice and the archaeological record}

The archaeological chronology of development and outflow of Neolithic lifestyles in the eastern Asian region can be summarized as follows (Bellwood 2005: chapters 6, 7, and 10; Zhang and Hung 2008, 2010; Fuller et al. 2010; Bellwood et al. 2011b):

1. 8,000-6,000 BC: Development of predomestication cereal agriculture in central China, with japonica rice in the Yangzi, Han, Huai, and lower Yellow river basins, and mostly foxtail and broomcorn millets to the west and north. Indica rice was domesticated in South Asia much later and played no role in the East Asian Neolithic.

2. 6,000-3,500 BC: Gradual spread of Neolithic lifestyles through southern China, accompanied by an increasing predominance, especially after 4,000 BC of fully domesticated (nonshattering) rice

3. 3,500 BC: Neolithic settlement of Taiwan (Dabenkeng culture), presumably following developments in Fujian and/or Guangdong (Jiao 2007; Tsang 2005)

4. 3,000-2,000 BC: Neolithic settlement of mainland Southeast Asia from Guangdong and Guangxi into northern Vietnam, and possibly down the Mekong river (or down the Southeast Asian coastline) into southern Vietnam and Thailand (Higham 2004; Oxenham et al. 2011; Bellwood et al. 2011a)

5. 2,000-1,500 BC: Neolithic settlement of the Philippines and central Indonesia, via Taiwan, and of the Mariana Islands from the northern Philippines (Bellwood and Hiscock 2009; Hung et al. 2011)

In my book First Farmers (Bellwood 2005), these Neolithic spreads are related mainly to the establishments of the Sino-Tibetan, Austroasiatic, and Austronesian language families, with the movements of Tai, TibetoBurman, and Hmong-Mien speakers being mainly postNeolithic. For the Chinese Neolithic heartland itself, 
especially along the Yellow River, we can read continuity of cultural development from Neolithic times into the Sinitic-speaking Chinese Bronze Age culture of the Shang Dynasty. For Austroasiatic, Higham (2004) and Rispoli (2007) equate the Neolithic movement through mainland Southeast Asia with the spread of rice cultivation and incised/stamped pottery from southern China (including Yunnan) into Vietnam, Thailand, Indochina, and Peninsular Malaysia after 2,500/2,000 BC. Offshore, the spread of Austronesian languages with Neolithic population movements from Taiwan to the Philippines and Indonesia is also now well documented archaeologically for the period between 2,000 and $1,500 \mathrm{BC}$ (Bellwood and Dizon 2005, 2008; Bellwood 2011; Bellwood et al. 2011b). However, in tropical Island Southeast Asia beyond Taiwan, a large number of native fruits and tubers were also incorporated into the economic repertoire, and rice and millet probably faded in significance as populations approached equatorial latitudes (Bellwood 1997).

The prehistory of rice cultivation in Island Southeast Asia is particularly obscure, no doubt in part due to a simple lack of specialized archaeobotanical research (Castillo and Fuller 2010). For instance, remains of rice and millet were universally absent from sites of the Dabenkeng phase in Taiwan $(3,500-2,500 \mathrm{BC})$ until both were found in unprecedented carbonized quantities dating to c.2,800 BC, in hitherto unique waterlogged conditions, in the Nanguanli sites in the Tainan Science-Based Industrial Park (Tsang 2005; Tsang et al. 2004). In fact, the list of sites in Island Southeast Asia in which evidence for rice has been found, particularly as a result of careful analysis of pottery or phytoliths, is rapidly increasing, especially in circumstances where carbonized macro-remains are absent. Numerous occurrences are now reported from Taiwan and Borneo (Bellwood 2011; Hsieh et al. this issue).

In addition, where morphological or genetic analysis has been carried out on carbonized rice grains from Southeast Asian sites that are more than 2,000 years old, available results all suggest the presence of japonica but not yet indica, hence supporting a model of Neolithic expansion southwards from China. Castillo (this issue) presents this conclusion for late Neolithic and Bronze Age Thailand, as do Hsieh et al. for Nanguanli in Taiwan. Katsunori Tanaka (in Bellwood et al. 2011a) has presented chloroplast DNA evidence that the rice chaff temper in pottery from Neolithic An Son in southern Vietnam (2,000-1,200 BC) was also from japonica rice. Indica rice does not make an appearance in Southeast Asia until about 2,000 years ago, contemporary with the beginnings of contact with India.

But one problem remains. Why was rice not carried by migrating Austronesians into and across Oceania?
Into a friction zone (Bellwood 2001: 189)

Moving eastwards beyond Borneo and Bali into Wallacea, we find that rice faded rapidly in importance prior to 1950 and never penetrated into or beyond New Guinea at all (Spencer 1966, Figs. 4 and 5). I have discussed this issue many times (Bellwood 1980, 1985, 1997, 2011) and refer here mainly to the discussion published in my Prehistory of the Indo-Malaysian Archipelago. In both editions of that book, I suggested that rice faded owing to the inherent unsuitability of the equatorial environment for its cultivation (mainly after Spencer 1966), and that early Austronesians were not entirely a population of avid rice cultivators but also contained subpopulations with maritime or foraging adaptations (as suggested by Sather 1995). They would have been precisely the kind of people we might expect to sail away by boat, probably without rice, to exploit the resources of new islands. Dewar (2003) has since developed the climatic argument in terms of an increasing unreliability of rainfall, inhibiting rice cultivation as one moves east through Island Southeast Asia towards eastern Melanesia. Neither Dewar nor I see evidence for a sometimes claimed early pre-rice phase of tuber and fruit cultivation in China or most of Southeast Asia, until one approaches the acknowledged and independent focus of fruit and tuber domestication in the New Guinea Highlands. It is possible that this spread into adjacent Melanesian lowland regions, including parts of eastern Indonesia (Donohue and Denham 2010; Lentfer et al. 2010), but the evidence for this is at present rather limited.

Was an unsupportive environment the main reason for the nonspread of rice eastwards? Rice undoubtedly found very supportive climatic and soil conditions in some nonequatorial islands south of the equator, such as Java and Bali, and it must have crossed the equator to reach them, suggesting that varieties that were insensitive to day length variation were selected for quite early on in the Austronesian migration process. Indeed, there is no obvious reason why rice should have disappeared altogether on approaching New Guinea. After all, many Pacific Island populations developed very intensive methods of wet field cultivation for aroids, and the New Guinea Highlands had a very long tradition of draining and managing swamps for the cultivation of Colocasia taro, so it is hard to imagine that the environment was totally to blame. If early speakers of Malayo-Polynesian (Extra-Formosan Austronesian) languages regarded rice highly, they would surely have tried to carry it with them on their migrations eastwards into some of the larger and better watered Pacific islands.

However, rice might have held little value for the indigenous non-Austronesian populations of eastern Indonesia and Melanesia (including New Guinea), especially in competition with tuber and fruit horticulture using vegeta- 
tive methods of planting. As Pelzer (1948: 7) once noted: "...a plant, the introduction of which involves a change in methods of cultivation, [will only be] accepted under pressure." New Guineans did not have grain crops, and relied on tubers and plants such as bananas and sugar cane that were planted vegetatively. Also, while mid-Holocene New Guineans did indeed manage water levels for raised bed and drained fields in swamps, they did not use the bunded wet field methods typical for wet taro in eastern Island Melanesia and Polynesia. So, a nonadoption of rice by non-Austronesians is perhaps to be expected. But its failure to travel with Malayo-Polynesian-speaking populations into other uninhabited regions of Oceania still remains surprising, given the suitability of many Oceanic islands for wet taro production.

I think the answer here may be a historical one, involving the precise directionality of ancient MalayoPolynesian colonization into Oceania. For many years, it has been assumed (including by me) that this emanated from eastern Indonesia at about 1,350 BC, most likely from Halmahera, and reached the Bismarck Archipelago by skirting the northern coastline of New Guinea, in the guise of the Lapita culture of archaeologists (e.g., Bellwood 1997). But there is no strong evidence for this scenario, and there are a number of points against it:

1. There is no secure linguistic evidence for deriving Proto-Oceanic specifically from south Halmahera or west New Guinea, except for Robert Blust's (e.g., 2009) placement of the Oceanic and south Halmahera/ west New Guinea subgroups of Malayo-Polynesian within a greater Eastern Malayo-Polynesian subgroup. But south Halmahera/West New Guinea is only weakly defined by shared innovations, and equally likely is a concept of an initial and rapid radiation over a very large area of a series of dialects of Proto-MalayoPolynesian, mostly still intercomprehensible owing to the short time of differentiation, at the beginning of the Island Southeast Asian Neolithic (c.2,000-1,500 BC). The formation of the extant subgroups of MalayoPolynesian would then have postdated this phase. Under such circumstances, the genesis of ProtoOceanic in the Bismarck or Admiralty Islands could have drawn on early and undifferentiated MalayoPolynesian linguistic resources from anywhere in Island Southeast Asia, both Philippines and Indonesia (and not just Halmahera or west New Guinea), as well as taking on indigenous Papuan loans in Melanesia (Donohue and Denham 2010).

2. Likewise, Chamorro is normally classified as a Western Malayo-Polynesian language today, but given the lack of any complete internal subgrouping for the Western Malayo-Polynesian languages, it is likely that it has acquired this status by virtue of not sharing any of the defining innovations of Proto-Oceanic. It might be more accurate to state merely that Chamorro is not an Oceanic language, without implying any particular subgrouping status for it, although its likely origin in the Philippines is well supported by comparative linguistics (Blust 2000; Reid 2002).

3. New Guinea itself appears to have played no direct role in the transmission eastwards of Malayo-Polynesian languages, and the establishment of them in much of Papua New Guinea was very marginal and late in time, possibly within the past 2,500 years (Ross 1988; Pawley 2002). Proto-Oceanic itself has generally been located by linguists in the Bismarck Archipelago, not in New Guinea itself, neither does New Guinea have significant early Lapita sites. The island itself appears not to have been involved in any early spread of Southeast Asian Neolithic artifact categories from Indonesia into Oceania.

4. Indeed, as the initial Neolithic culture of Oceania, Lapita had no visible origin in the eastern Indonesian Neolithic at all. Perhaps, like the Talasea (New Britain) obsidian excavated from layers dated to c.1,000 BC in the rock shelter of Bukit Tengkorak in Sabah (Bellwood 1997), the very few pottery finds in Indonesia with decoration that resembles late Lapita represent an east to west movement from the Bismarcks, rather than vice versa.

On the other hand, the "Pacific" mtDNA clade of pigs associated with Lapita dispersal originated on the northern mainland of Southeast Asia or southern China, and did not apparently travel into Oceania via Taiwan or the Philippines (Larson et al. 2010). So this might have traveled via Indonesia. But this need not imply an Indonesian origin for the Lapita population, or its pots, or its Proto-Oceanic language because pigs could easily have been transmitted as commodities via exchange back along the same route that brought the Talasea obsidian in the other direction to Borneo. There is no reason why a species or lineage of domesticated animal needs travel as part of a significant human migration; dingoes (dogs) reached Australia in prehistoric times with no trace of any human migration at all.

To explain the lack of Lapita connections in eastern Indonesia, it has recently been proposed that the initial movement of Malayo-Polynesian speakers into Oceania went from the northern Philippines eastwards to the Mariana Islands, then down from there southwards into the Bismarcks (Hung et al. 2011; Bellwood 2011). Later, but prior to any significant differentiation of Proto-Oceanic, movement continued back around the north side of New Guinea into eastern Indonesia. This movement carried the 
distinctive zonal elements of Lapita red-slipped pottery decoration from Luzon via the Marianas into the Bismarcks, but the huge open sea distances involved (c.2,300 km on both legs) meant that neither rice nor pigs survived the voyages. There is no dry land between Luzon and Guam, and 3,500 years ago, the Micronesian atolls were not yet emergent (Dickinson 2003). So the distances of unbroken ocean that had to be crossed were immense, as no doubt were the difficulties of keeping alive stocks of rice, pigs, and dogs during voyages in small canoes with little weather or sea spray protection. It is worth adding that the specific style of pottery referred to above as linking Luzon, the Marianas, and Lapita has never been found in Yap or Palau, both subjected to intensive archaeological survey in recent years.

Pigs and dogs are not reported at all from Marianas prehistory, although a limited amount of rice growing was attested there in the seventeenth century, albeit not recorded by Antonio Pigafetta in 1521 (Nowell 1962: 130-131). Blust (2000: 109) suggests that Chamorro has inherited rice-associated vocabulary directly from Proto-Austronesian and that rice must have been taken there in prehistory. Perhaps so, but there is as yet no archaeological evidence for its presence in the Marianas, and even if it did reach the Marianas, it is unlikely to have traveled successfully onwards to the Bismarcks by that route. This probably means that the founders of Proto-Oceanic arrived in the Bismarcks from the Marianas with linguistic resources very close to Proto-Malayo-Polynesian, but without pigs and rice. The pigs came rapidly later from Indonesia, the rice never.

Rice, therefore, was not taken into Oceania for two reasons:

1. The initial Malayo-Polynesian migration from the Philippines, via the Marianas, to the Bismarcks took place under circumstances too difficult for viable rice seed stock to get through, and the same applies to pigs and presumably to all other domesticated animals via that particular route.

2. The movement of rice southeastwards through Indonesia eventually ceased owing to the presence of a resistant Papuan-speaking population, still dominant today in New Guinea, that had no interest in its adoption as a viable crop. The density and food-producing status of this indigenous population brought the Malayo-Polynesian migration to a linguistic and genetic standstill in the southeastern corner of Indonesia (Lansing et al. 2011; Cox et al. 2010; Karafet et al. 2010). There is really no clear evidence at all for any migration of MalayoPolynesian-speaking populations from west to east in the vicinity of New Guinea, neither to its north nor to its south, and it is suggested here that they moved in the opposite direction, from the Bismarcks to Indonesia. Malayo-Polynesian migration in the western Pacific was thereby a massive clockwise circle rather than a one-way arrow that always headed east.

\section{Conclusions}

In my Prehistory of the Indo-Malaysian Archipelago (Bellwood 1985, 1997: 249-254), I suggested three successive phases for the prehistory of rice cultivation in southern China and Southeast Asia. The first, from southern China to Taiwan and the northern Philippines, involved both localized swamp cultivation and dry land shifting cultivation. The second involved mostly shifting cultivation as Austronesian-speaking populations moved through the Philippines into the equatorial zone and towards eastern Indonesia, and also a gradual demise of rice in the face of the indigenous tubers and fruits that were more suited to perhumid and equatorial environmental conditions. The third phase saw the establishment of wet rice cultivation after $500 \mathrm{BC}$ in regions of high population growth such as Java and Bali, especially in fertile volcanic landscapes where terracing could be constructed. Wet rice did not always require a state-level organization, as we can see from the Mountain Province (Ifugao) terraces in northern Luzon. But my suspicion is that it required both good sources of irrigation water and an increasing population, no doubt operating in a mutualistic relationship akin to Geertz' (1963) concept of agricultural involution.

This outline still seems acceptable to me, but now, we understand much better the earlier archaeological sequence towards rice domestication in China. The core developmental sequence in the Yangzi Basin and adjacent areas, from wild rice management to intensive wet field construction, occupied the millennia from about 7,000 to 4,000 BC. By the time that rice cultivation was spreading into regions such as Vietnam and Taiwan (c.3,000 to 2,000 BC), the inner part of the Yangzi Basin had become locked into a cycle of wet rice intensification and geographic inertia that would have slowed down any inclination for migration on the part of the core populations themselves, unless adverse environmental conditions altered the situation drastically. There is indeed some evidence that stress factors might have afflicted lower Yangzi populations during the Maqiao phase between 1,900 and 1,200 BC (Chen et al. 2005), but this seems a little late in time as an explanation for rice expansion, given that rice farmers had already been in Taiwan for about a millennium beforehand.

Regardless of whether or not serious mid-Holocene climatic change actually occurred in the Yangzi Basin, the situation of increasing social complexity would have brought peripheral populations into more frequent domino 
relationships with the core groups, magnified no doubt if that core was suffering from periodic climatic downturns or marine transgressions. Peripheral populations who adopted cultivation of a rice plant that had already been domesticated in the Yangzi Basin could thus have been stimulated by domino impacts to search for new land to the south, utilizing shifting dry land agriculture on sloping ground and occasional small scale swamp cultivation along the rivers and drowned shorelines of southern China and Southeast Asia. Foxtail millet also traveled with these movements, to at least as far as Taiwan and central Thailand (Sagart 2008; Weber et al. 2010). Linguistically, from this perspective, the homelands of the major language families of Southeast Asia, such as Austronesian, Tai, and Austroasiatic, were probably located not in the Yangzi Basin proper but in regions more peripheral, either to the north (cf. Sagart 2005a, 2008 for Austronesian) or to the south.

Shifting cultivation of rice failed to penetrate Oceania, not only because of the presence of indigenous and fairly entrenched tuber and fruit horticulturalists in Melanesia and eastern Indonesia but also because the first Austronesian movement into Oceania took place over an impossible route, across 2,300 open $\mathrm{km}$ of sea from the Philippines to the Mariana Islands and then over a similar distance from the Marianas to the Bismarck Archipelago. Neither pigs nor rice (nor dogs nor chickens) survived that ordeal, as neither did the cereal stocks carried by the First Fleet that reached Sydney Cove from the other side of the world in 1788. But the British had good backup supplies. The first Austronesians to reach the Marianas were not so fortunate.

\section{References}

Allaby R, Fuller D, Brown T. The genetic expectations of a protracted model for the origins of domesticated crops. Proc Natl Acad Sci U S A. 2008;105:13982-6.

Bellwood P. Indonesia, the Philippines and Oceanic prehistory. J Soc des Océan. 1980;36(66-67):148-55.

Bellwood P. Prehistory of the Indo-Malaysian Archipelago. Sydney: Academic; 1985.

Bellwood P. Prehistory of the Indo-Malaysian Archipelago. 2nd ed. Honolulu: University of Hawaii Press; 1997.

Bellwood P. Early agriculturalist population diasporas? Farming, languages and genes. Annu Rev Anthropol. 2001;30:181-207.

Bellwood P. First Farmers: the origins of agricultural societies. Oxford: Blackwell; 2005.

Bellwood P. Holocene population history in the Pacific region as a model for world-wide food producer dispersals. Curr Anthropol. 2011;52(S4):363-78.

Bellwood P, Dizon E. The Batanes Archaeological Project and the "Out Of Taiwan" hypothesis for Austronesian dispersal. J Austronesian Stud. 2005;1:1-33. Taitung, Taiwan.

Bellwood P, Dizon E. Austronesian cultural origins: out of Taiwan, via the Batanes Islands, and onwards to western Polynesia. In: Sanchez-Mazas A, Blench R, Ross MD, Peiros I, Lin M, editors. Past human migrations in East Asia: matching archaeology, linguistics and genetics. London: Routledge; 2008. p. 23-39.

Bellwood P, Hiscock P. Holocene Australia and the Pacific Basin. In: Scarre C, editor. The human past. 2nd ed. London: Thames and Hudson; 2009. p. 264-305.

Bellwood P, Stevenson J, Dizon E, Mijares A, Lacsina G, Robles E. Where are the Neolithic landscapes of Ilocos Norte? Hukay. 2008; 13:25-38. Manila.

Bellwood P, Oxenham M, Hoang BC et al. An Son and the Neolithic of southern Vietnam. Asian Perspectives; 2011 (in press).

Bellwood P, Chambers G, Ross M, Hung H-C. Are "cultures" inherited? Multidisciplinary perspectives on the origins and migrations of Austronesian-speaking peoples prior to $1000 \mathrm{BC}$. In: Roberts B, Van der Linden M, editors. Investigating archaeological cultures: material culture, variability and transmission. Dordrecht: Springer; 2011b. p. 321-54.

Blust R. Chamorro historical phonology. Oceanic Linguistics. 2000;39:83-122.

Carson M. Palaeohabitat of first settlement sites 1500-1000 BC in Guam. Mariana Islands. J Archaeological Sci. 2011;38:220721.

Castillo C, Fuller D. Still too fragmentary and dependent upon chance? In: Bellina B et al., editors. 50 Years of archaeology in Southeast Asia. Bangkok: River Books; 2010. p. 93111.

Chen Z, Wang Z, Schneiderman J, et al. Holocene climatic fluctuations in the Yangtze delta of eastern China and the Neolithic response. Holocene. 2005;15:915-24.

Cox M, Karafet T, Lansing JS, et al. Autosomal and X-linked SNPs reveal a sharp transition from Asian to Melanesian ancestry in Eastern Indonesia and a female bias in admixture rates. Proc Roy Soc London Ser B. 2010;277:1589-96.

Dewar R. Rainfall variability and subsistence systems in Southeast Asia and the western Pacific. Curr Anthropol. 2003;44:369-88.

Dickinson W. Impact of Mid-Holocene hydro-isostatic highstand in regional sea level on habitability of islands in Pacific Oceania. J Coastal Res. 2003;19:489-502.

Diffloth G. The contribution of linguistic palaeontology to the homeland of Austro-asiatic. In: Sagart L et al., editors. The peopling of East Asia. London: Routledge Curzon; 2005. p. 77-80.

Diffloth G. Austroasiatic word histories: boast, husked rice and taro. In: Enfield N, editor. Dynamics of human diversity. Canberra: Pacific Linguistics; 2011.

Donohue M, Denham T. Farming and language in Island Southeast Asia; reframing Austronesian history. Curr Anthropol. 2010;51:223-56.

Ferlus M. The Austroasiatic vocabulary for rice: its origin and expansion. J SE Asian Linguistics Soc. 2010;3.2:61-76.

Freeman D. Report on the Iban. London: Athlone Press; 1970.

Fuller D, Qin L. Water management and labor in the origins and dispersal of Asian rice. World Archaeol. 2009;41:88-111.

Fuller D, Qin L, Zheng Y, et al. The domestication process and domestication rate in rice. Science. 2009;323:1607-10.

Fuller D, Sato Y-I, Castillo C, et al. Consilience of genetics and archaeobotany in the entangled history of rice. Archaeol Anthropol Sci. 2010;2:115-31.

Fuller D, van Etten J, Manning K, et al. The contribution of rice agriculture and livestock pastoralism to prehistoric methane levels. Holocene. 2011;21:743-59.

Geertz C. Agricultural involution. Berkeley: University of California Press; 1963.

Higham C. Mainland Southeast Asia from the Neolithic to the Iron Age. In: Glover I, Bellwood P, editors. Southeast Asia: from prehistory to history. London: Routledge Curzon; 2004. p. 4167. 
Hill R. The cultivation of perennial rice, an early phase in Southeast Asian agriculture? Paper presented at the Conference of the Indo-Pacific Prehistory Association, Hanoi, Vietnam; 2009.

$\mathrm{Hu}$ Y, Ambrose S, Wang C. Stable isotopic analysis of human bones from Jiahu site. J Archaeological Sci. 2006;33:1319-30.

Hung H-C. Neolithic interaction between Taiwan and northern Luzon: the pottery and jade evidences from the Cagayan Valley. J Austronesian Stud. 2005;1(1):109-34.

Hung H-C, Carson M, Bellwood P, Campos F, et al. The first settlement of remote Oceania: Luzon to the Marianas. Antiquity. 2011;85:990-26.

Jiang L, Liu L. New evidence for the origins of sedentism and rice domestication in the lower Yangtze river, China. Antiquity. 2006;80:355-61.

Jiao T. The Neolithic of southeast China. Youngstown: Cambria; 2007.

Karafet T, Hallmark B, Cox M, et al. Major east-west division underlies Y-chromosome stratification across eastern Indonesia. Mol Biol Evol. 2010;27:1833-44.

Kirch PV. The wet and the dry. Chicago: University of Chicago Press; 1994.

Kirch PV. How chiefs became kings. Berkeley: University of California Press; 2010.

Lansing J, Cox M, de Vet $\mathrm{T}$, et al. An ongoing Austronesian expansion in Island Southeast Asia. J Anthropol Archaeol. 2011;30:262-72.

Larson G, Liu R, Zhao X, et al. Patterns of East Asian pig domestication, migration, and turnover revealed by modern and ancient DNA. Proc Natl Acad Sci U S A. 2010;107:768691.

Lentfer C, Pavlides C, Specht J. Natural and human impacts in a 35,000 year vegetation history in central New Britain. Quat Sci Rev. 2010;29:3750-67.

Li X, Dodson J, Zhou J, Zhou X. Increases of population and expansion of rice agriculture in Asia, and anthropogenic methane emissions since 5000 BP. Quat Int. 2009;202:41-50.

Liu Y. The earliest Austronesians and their movements inside Taiwan. In: Chiu S, Sand C, editors. From Southeast Asia to the Pacific. Taipei: Center for Archaeological Studies, Academia Sinica; 2007. p. 49-74.

Liu L, Lee G, Jiang L, Zhang J. Evidence for the early beginning (c. 9000 cal. BP) of rice domestication in China: a response. Holocene. 2007; 17:1059-68.

McGovern P, Zhang J, Tang J, et al. Fermented beverages of pre- and proto-historic China. PNAS. 2004:101:17593-8.

Molina J, Sikora M, Garud N et al. Molecular evidence for a single origin of domesticated rice. PNAS; 2011 (in press).

Nakamura S-I. The origin of rice cultivation in the lower Yangtze region, China. Archaeol Anthropol Sci. 2010;2:107-14.

Nowell C, editor. Magellan's voyage around the world. Evanston: Northwestern University Press; 1962.

Oxenham, M., H. Matsumura and K.D. Nguyen eds. 2011. Man Bac: the Excavation of a Neolithic Site in Northern Vietnam. Canberra: Terra Australis vol. 33, ANU E Press.

Pawley A. The Austronesian dispersal: languages, technologies and people. In: Bellwood P, Renfrew C, editors. Examining the farming/language dispersal hypothesis. Cambridge: McDonald Institute for Archaeological Research; 2002. p. 251-74.

Pelzer KJ. Pioneer settlement in the Asiatic tropics. New York: American Geographical Society; 1948.

Proske U, Hanebuth T, Behling H, Nguyen V, et al. The palaeoenvironmental development of the northeastern Vietnamese Mekong River Delta since the mid-Holocene. Holocene. 2010;20:1257-68.
Ratliff M. Hmong-Mien language history. Canberra: Pacific Linguistics; 2010 .

Reid LA. Morphosyntactic evidence for the position of Chamorro in the Austronesian language family. In: Bauer R, editor. Collected papers on Southeast Asian and Pacific languages. Canberra: Pacific Linguistics; 2002. p. 63-94.

Rispoli F. The incised and impressed pottery of Mainland Southeast Asia: following the paths of Neolithization. East West. 2007;57:235-304

Rolett B, Zheng Z, Yue Y. Holocene sea-level change and the emergence of Neolithic seafaring in the Fuzhou Basin. Quat Sci Rev. 2011;30:788-97.

Ross MD. Proto-Oceanic and the Austronesian languages of Western Melanesia. Canberra: Pacific Linguistics Series C98; 1988.

Sagart L. The vocabulary of cereal cultivation and the phylogeny of East Asian languages. Bull Indo-Pacific Prehistory Assn. 2003;2:127-36.

Sagart L. Sino-Tibetan-Austronesian: an updated and improved argument. In: Sagart L, Blench R, Sanchez-Mazas A, editors. The peopling of East Asia. London: Routledge Curzon; 2005a. p. $161-76$.

Sagart L. Tai-Kadai as a subgroup of Austronesian. In: Sagart L, Blench R, Sanchez-Mazas A, editors. The peopling of East Asia. London: Routledge Curzon; 2005b. p. 177-81.

Sagart L. The expansion of Setaria farmers in East Asia. In: SanchezMazas A et al., editors. Past human migrations in East Asia. London: Routledge Curzon; 2008. p. 133-57.

Sather C. Sea nomads and rainforest hunter-gatherers. In: Bellwood P, Fox J, Tryon D, editors. The Austronesians. Canberra: Australian National University, Dept. Anthropology Research School of Pacific and Asian Studies; 1995. p. 229-68.

Sathiamurthy E, Voris H. Maps of Holocene sea level transgression and submerged lakes on the Sunda Shelf. Natural History Journal of Chulalongkorn University. 2006; Suppl2:1-43.

Sidwell P. The Austroasiatic central riverine hypothesis. Journal of Language Relationship (Moscow). 2010;4:117-34.

Smith D, Harrison S, Firth C, Jordan J. The early Holocene sea level rise. Quat Sci Rev. 2011;30:1846-60.

Spencer JE. Shifting cultivation in southeastern Asia. Berkeley: University of California Press; 1966.

Spriggs M. Geomorphic and archaeological consequences of human arrival and agricultural expansion on Pacific islands. In: Haberle S, Stevenson J, Prebble M, editors. Altered ecologies. Canberra: Terra Australis 32, ANU E Press; 2011. p. $239-52$.

Tsang C-H. Archaeology of the P'eng-hu Islands. Taipei: Institute of History and Philology, Academia Sinica; 1992.

Tsang C-H. Recent discoveries at a Tapenkeng culture site in Taiwan: implications for the problem of Austronesian origins. In: Sagart L, Blench R, Sanchez-Mazas A, editors. The peopling of East Asia. London: Routledge Curzon; 2005. p. 63-73.

Tsang C-H, Li K-T, Chu C-Y. Report on Daoye Site, Tainan ScienceBased Industrial Park. Taipei: Academia Sinica; 2004. in Chinese.

Vayda A. Expansion and warfare among swidden agriculturalists. Am Anthropol. 1961;63:346-58.

Weber S, Lehman H, Barela T, et al. Rice or millets: early farming strategies in prehistoric central Thailand. Archaeol Anthropol Sci. 2010;2:79-88.

Wolff J. Proto-Austronesian phonology with glossary. 2 volumes. Ithaca: Cornell Southeast Asia Program Publications; 2010.

Yan W. China's earliest rice agriculture remains. Bull Indo-Pacific Prehistory Assn. 1991;10:118-26. 
Zhang C, Hung H-C. The Neolithic cultures of southern China: origin; development and dispersal. Asian Perspect. 2008;47 (2):299-330.

Zhang $\mathrm{C}$, Hung $\mathrm{H}-\mathrm{C}$. The emergence of agriculture in southern China. Antiquity. 2010;84:11-25.

Zhao J. New data and new issues for the study of origin of rice agriculture in China. Archaeol Anthropol Sci. 2010;2:99-106.

Zheng Y, et al. Rice fields and modes of rice cultivation between 5000 and $2500 \mathrm{BC}$ in east China. J Archaeol Sci. 2009; $36: 2609-16$
Zong Y, Chen Z, Innes J, et al. Fire and flood management of coastal swamp enabled first rice paddy cultivation in east China. Nature. 2007;449:459-62.

Zorc D. Austronesian culture history through reconstructed vocabulary. In: Pawley A, Ross M, editors. Austronesian terminologies: continuity and change. Canberra: Pacific Linguistics Series C127; 1994. p. 541-95.

ZPICRA (Zhejiang Provincial Institute of Cultural Relics and Archaeology). Kua Hu Qiao. Beijing: Cultural Relics Publishing House; 2004. in Chinese. 